\title{
Air pollution-related deaths in Europe - time for action
}

\section{Helotonio Carvalho}

Department of Biophysics and Radiobiology, Biological Sciences Centre, Federal University of Pernambuco, Recife, PE, Brazil Department of Immunology, Aggeu Magalhães Research Institute (IAM), Oswaldo Cruz Foundation (FIOCRUZ), Recife, PE, Brazil

$\mathrm{D}$ espite some advances, poor air quality in Europe persists, even in high-income countries. According to the latest report from the European Environmental Agency (EEA), more than 500000 people died in Europe in 2015 due to air pollution [1]. This corresponds to about one sixth of all deaths related to air pollution in the world. The EEA data take into account deaths caused by $\mathrm{PM}_{2.5}$ (particulate material with less than $2.5 \mu \mathrm{m}$ in diameter), $\mathrm{NO}_{2}$ and ozone. Particulate material has been recognized as the main risk factor associated to air pollution. About $83 \%$ of all deaths related to air pollution in Europe in 2015 were attributed to $\mathrm{PM}_{2,5}, 14 \%$ to $\mathrm{NO}_{2}$ and the remaining deaths were attributed to ozone. An analysis of the countries with more deaths attributed to air pollution reveals that Italy, Germany, Poland, France and UK, in this order, are at the top of the list (Table 1). Spain, Romania, Bulgaria, Greece and Hungary complete the 10 countries with more deaths caused by air pollution. If we look at the countries with higher death rates, the list changes considerably, including Eastern and Southern European countries as the leading ones, with Kosovo, Bulgaria, Serbia, Macedonia and Hungary at the top

Table 1. European countries with more deaths attributable to air pollution, according to the Air Quality Report 2018

\begin{tabular}{|c|c|c|c|c|c|c|}
\hline Rank & Countay & Premature deaths [1] & $\begin{array}{c}\text { Annual mean PM }{ }_{2.5}^{*} \\
\left(\mu \mathrm{e} / \mathrm{m}^{3}\right)[1]\end{array}$ & $\begin{array}{l}\text { \% DIESEL VEHICLES } \\
\text { IN USE [2] }\end{array}$ & $\begin{array}{l}\text { Average aGe of } \\
\text { VehicLes [3] }\end{array}$ & $\begin{array}{l}\text { \% EnERGY Produced } \\
\text { From COAL [4] }\end{array}$ \\
\hline 1 & Italy & 84300 & 18.5 & 41.1 & 10.7 & 16.7 \\
\hline 2 & Germany & 78400 & 12.3 & 32.2 & 8.9 & 45.8 \\
\hline 3 & Poland & 47500 & 21.6 & 29.4 & 17.2 & 80.9 \\
\hline 4 & France & 47300 & 11.9 & 69.8 & 9.0 & 2.2 \\
\hline 5 & United Kingdom & 41490 & 9.4 & 37.2 & 8.5 & 22.9 \\
\hline 6 & Spain & 38600 & 12.7 & 56.6 & 11.4 & 16.5 \\
\hline 7 & Romania & 27280 & 18.1 & 37.0 & 15.3 & 27.6 \\
\hline 8 & Bulgaria & 15190 & 24.1 & 48.4 & $\mathrm{NA}^{\dagger}$ & 46.2 \\
\hline 9 & Greece & 14910 & 19.1 & 4.9 & 13.5 & 42.7 \\
\hline 10 & Hungary & 14630 & 18.9 & 27.8 & 14.5 & 19.5 \\
\hline 11 & Serbia & 14280 & 23.3 & NA & NA & 72.4 \\
\hline 12 & Netherlands & 11990 & 12.3 & 16.5 & 9.5 & 37.3 \\
\hline 13 & Czech Republic & 11050 & 17 & 35.3 & 14.5 & 54.0 \\
\hline 14 & Belgium & 9120 & 13 & 61.5 & 8.8 & 6.3 \\
\hline 15 & Austria & 7480 & 13.3 & 56.9 & 8.9 & 8.2 \\
\hline
\end{tabular}

* $\mathrm{PM}_{2.5}$ - particulate material with less than $2.5 \mu \mathrm{m}$ in diameter.

$\dagger \mathrm{NA}$ - not available. 
of the list (Table 2) and also includes Italy, Greece, Romania, Poland and Croatia. These data show that despite stricter rules for car emissions, there are unjustifiable high numbers of deaths related to air pollution in many European countries. The annual mean $\mathrm{PM}_{2.5}$ levels for most of the countries with higher death rates are close to or twice as high as the WHO recommended levels of $10 \mu \mathrm{g} / \mathrm{cm}^{3}$, and all the countries listed in Table 1 and Table 2, except UK, show $\mathrm{PM}_{2.5}$ levels above this limit.

Especially in the case of Italy, Germany, France and UK, the high number of deaths related to air pollution might be related to the high number of diesel cars [2], which account for 30 to almost $70 \%$ of all vehicles registered in these countries (Table 1). This is also true for many Eastern and Southern European countries such as Bulgaria, Macedonia, Lithuania, Croatia and Latvia. Another factor that contributes to air pollution-related deaths is the use of coal for electricity generation. Among the fuels used in power stations, coal is the most polluting one, releasing more particulate material than any other fossil fuel. The percentage of electricity generated by coal burning is low in France (Table 01), which relies mostly on nuclear power. However, its importance in UK, Germany, Greece, Czech Republic and particularly Poland, Serbia and Macedonia is much higher, reaching at least 60\% in the later countries [4]. In Kosovo, almost all the electricity is produced from coal.

Air quality is also highly affected by the age of the vehicle fleet, since older cars have higher emission levels. On the list of countries with higher death rates, the average age of vehicles is above 13 years in most of the countries [3], with predominance of more polluting Euro 3 and Euro 4 vehicles. This is especially the case of Poland, Romania, Hungary and Czech Republic with an average age of vehicles over 14 years. Countries with the lowest death rates show an average vehicle age below 9 years (data not shown), with predominance of vehicles that have, at least, Euro 5 emission standards. Older cars reflect directly on air quality: all the countries in which they are more abundant have also the highest $\mathrm{PM}_{2.5}$ annual means. During many years, the import of used cars, especially to Eastern and Southern European countries, has been very common and certainly contributed to the poorer air quality in these countries [5]. Some countries are taking measures to restrict the age of used imported cars [6]. However, the Volkswagen emission scandal may have even worsened this problem, since countries with stricter environmental rules allowed sending cars involved in the scandal to other countries [7].

Another factor that contributes to air pollution in Europe, but only recently has received more attention, is related to shipping emissions. The contribution of shipping emissions to particulate material air pollution varies according to the fuel type, diesel or heavy fuel oil. Diesel used in ships is already more pollutant than the one used in heavy vehicles due to less stringent regulations. Heavy fuel oil is even more pollutant due to a much higher sulphur content than ordinary diesel. Shipping emissions are also affected by the region analysed and the method used on the study [8] and is more important in countries closer to the busy shipping routes of North Sea and the Mediterranean region. In the North Sea, the

Table 2. European countries with higher death rates attributable to air pollution, according to the Air Quality Report 2018

\begin{tabular}{|c|c|c|c|c|c|c|}
\hline Rank & Countay & $\begin{array}{c}\text { Deaths by } 100000 \\
\text { INHABItANTS [1] }\end{array}$ & $\begin{array}{c}\text { ANNUAL MEAN PM } \\
\left(\mu \mathrm{g} / \mathrm{m}^{3}\right)^{*}[1]\end{array}$ & $\begin{array}{c}\% \text { DIESEL VeHICLES IN } \\
\text { USE [2] }\end{array}$ & $\begin{array}{c}\text { Average AGE OF } \\
\text { VEHICLES [3] }\end{array}$ & $\begin{array}{l}\% \text { ENERGY PRODUCED } \\
\text { FROM COAL [4] }\end{array}$ \\
\hline 1 & Kosovo & 215.5 & 26.4 & $\mathrm{NA} \dagger$ & NA & 97.5 \\
\hline 2 & Bulgaria & 210.9 & 24.1 & 48.4 & NA & 46.2 \\
\hline 3 & Serbia & 200.7 & 23.3 & NA & NA & 72.4 \\
\hline 4 & Macedonia & 154.7 & 28.7 & 42.5 & NA & 58.4 \\
\hline 5 & Hungary & 148.4 & 18.9 & 27.8 & 14.5 & 19.5 \\
\hline 6 & Italy & 138.7 & 18.5 & 41.1 & 10.7 & 16.7 \\
\hline 7 & Greece & 137.3 & 19.1 & 4.9 & 13.5 & 42.7 \\
\hline 8 & Romania & 137.3 & 18.1 & 37.0 & 15.3 & 27.6 \\
\hline 9 & Poland & 125.0 & 21.6 & 29.4 & 17.2 & 80.9 \\
\hline 10 & Croatia & 122.1 & 17.4 & 43.3 & 14.1 & 20.6 \\
\hline 11 & Montenegro & 110.9 & 18.5 & NA & NA & 50.3 \\
\hline 12 & Bosnia and Herzegovina & 105.1 & 18.9 & 52.2 & NA & 64.0 \\
\hline 13 & Czech Republic & 104.9 & 17 & 35.3 & 14.5 & 54.0 \\
\hline 14 & Slovenia & 99.9 & 17.4 & 43.9 & 11.2 & 29.6 \\
\hline 15 & Slovakia & 99.8 & 19.1 & 7.9 & 13.4 & 11.9 \\
\hline
\end{tabular}

* $\mathrm{PM}_{2.5}$ - particulate material with less than $2.5 \mu \mathrm{m}$ in diameter.

$\uparrow \mathrm{NA}$ - not available. 


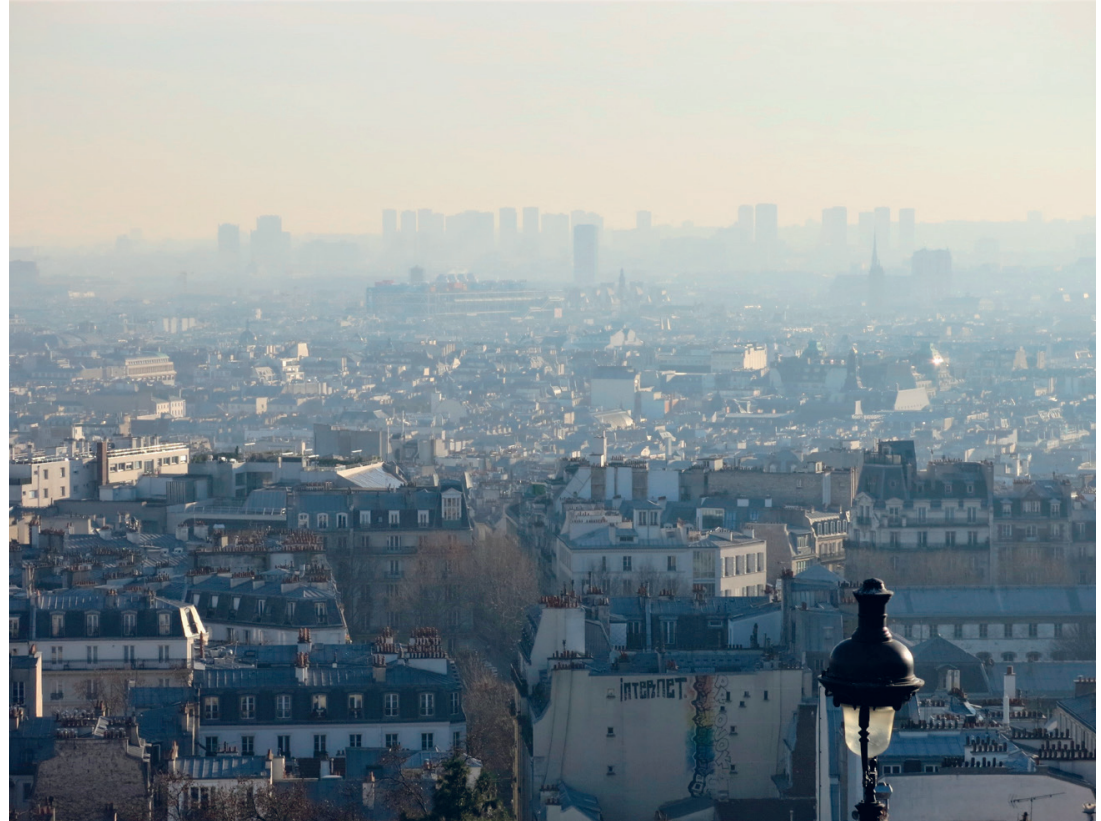

Photo: Pollution event in Paris, 8 December 2016 - Paris seen from the hill of Montmartre (Source: Wikimedia Commons, released into the public domain worldwide). contribution of shipping emissions to $\mathrm{PM}_{2,5}$ levels may be as high as $5 \%$ in the Netherlands and 4\% in UK. In the Mediterranean region, shipping emissions have been found to increase $\mathrm{PM}_{2,5}$ levels by as much as $14 \%$ in the Gibraltar Strait and 6\% in Barcelona (8). $\mathrm{PM}_{1}$ (particulate material with less than 1.0 $\mu \mathrm{m}$ in diameter) levels were increased by $20 \%$ in Genoa during summer that, according Viana et al. [8], is probably due to the increase in the number of passenger ships in this period.

Reducing the levels of air pollution is complex and involves public awareness, policy measures, and technological advances. In order to reduce air pollution levels, some Eastern European countries have proposed restrictions or even the ban of diesel cars, especially after the Volkswagen emission scandal [9], along with the implementation of low and ultra-low emission zones at city level. This energy transition is highly dependent on zero-emission cars development and adoption, what has been happening in a much higher speed in Norway, for example, where electric cars currently represent about $60 \%$ of all new car sales [10]. In Norway, as well as in most of the other countries where electric cars are significantly rising in sales, public incentives through lower taxes, besides other measures, have been a key factor for this change, which has been accompanied by an increase in public awareness, further catalysed by the Volkswagen emission scandal. The European Air Quality Index, launched last year, is also an important tool to increase awareness about air pollution among the European population [11]. However, much more needs to be done in order to reduce the number of deaths caused by air pollution in Europe. Regarding shipping emissions, the strictest fuel regulations, limiting sulphur content of shipping fuels, besides other parameters, are supposed to be adopted in 2020. These regulations are fundamental to reduce particulate material as well as $\mathrm{SO}_{\mathrm{x}}$ and $\mathrm{NO}_{\mathrm{x}}$ derived from shipping emissions [12]. While the increase in the number of electric cars is also fundamental for reducing air pollution levels in Europe, this needs to be accompanied by a complete energy matrix transition, which involves banning coal use. The use of coal for electricity generation has been falling in UK and Germany, for instance, and both countries have plans to phase out coal: UK in 2025 [13] and Germany between 2035 and 2038 [14]. Nevertheless, while the decrease in coal use has been faster in UK, Germany, the first economy in Europe and forth in the world, is still highly dependent on coal. Additionally, the high coal dependence in many Western and Southern European countries, which have been using cheap coal energy to speed up economic development, is a major issue that also needs to be addressed. It is time to speed up coal ban in favour of cleaner energy sources, a measure that, along with restrictions in the use of fossil fuels in vehicles, will help to improve air quality and reduce deaths caused by air pollution in Europe.

Acknowledgments: I thank my partners at Department of Biophysics and Radiobiology, Federal University of Pernambuco and Aggeu Magalhães Research Institute for the helpful discussions.

Funding: None.

Authorship contributions: HC designed, collected and analysed the data, wrote and revised the manuscript.

Competing interests: The author has completed the Unified Competing Interest form at www.icmje.org/coi_disclosure.pdf (available on request from the corresponding author) and declares no conflict of interest. 
1 Air Quality in Europe. 2018, European Environmental Agency. Available: https://www.eea.europa.eu//publications/ air-quality-in-europe-2018. Accessed: 29 October 2018.

2 Passenger cars in the EU update 2017 v2 (Eurostat). Available: https://ec.europa.eu/eurostat/statistics-explained/index. php?title=Passenger_cars_in_the_EU. Accessed: 29 October 2018.

3 Vehicles in Use: European Automobile Manufacturers' Association. Available: https://www.acea.be/statistics/tag/category/ vehicles-in-use. Accessed: 29 October 2018.

4 The World Bank. Electricity production from coal sources. Available: https://data.worldbank.org/indicator/EG.ELC.COAL. ZS. Accessed: 29 October 2018.

5 Germany's dirty diesel cars en route for Eastern Europe. Available: https://www.dw.com/en/germanys-dirty-diesel-carsen-route-for-eastern-europe/a-40224565. Accessed: 15 October 2018.

6 EUROPE. Cyprus joins campaign to curb EU imports of older used cars. Available: http://www.financialmirror.com/ news-details.php?nid=36034. Accessed: 25 October, 2018.

7 Western Europe brushes its dirty diesel cars under the Polish carpet. Available: https://www.transportenvironment.org/ press/western-europe-brushes-its-dirty-diesel-cars-under-polish-carpet. Accessed: 25 October 2018.

8 Viana M, Hammingh P, Colette A, Querol X, Degraeuwe B, de Vlieger I, et al. Impact of maritime transport emissions on coastal air quality in Europe. Atmos Environ. 2014;90:96-105. doi:10.1016/j.atmosenv.2014.03.046

9 Carvalho H. The end of diesel-powered cars? Lancet Respir Med. 2016;4:e2-3. Medline:26762666 doi:10.1016/S22132600(15)00475-0

10 For the first time ever, electric cars outsold gas and diesel vehicles in Norway. Available: https://edition.cnn.com/2019/04/04/ world/norway-zero-emission-vehicles-trnd/index.html. Accessed: 19 June 2019.

11 European Air Quality Index: current air quality information at your finger tips. Available: https://www.eea.europa.eu/ highlights/european-air-quality-index-current. Accessed: 15 October 2018.

12 Air pollution from ships. Available: https://www.transportenvironment.org/what-we-do/shipping/air-pollution-ships. Accessed: 19 June 2019.

13 UK government spells out plan to shut down coal plants. Available: https://www.theguardian.com/business/2018/jan/05/ uk-coal-fired-power-plants-close-2025. Accessed: 29 October 2018.

14 Germany's RWE says too early to exit coal in 2035. Available: https://www.reuters.com/article/us-rwe-coal/germanysrwe-says-too-early-to-exit-coal-in-2035-idUSKCN1LWOGM. Accessed: 29 October 2018.

\section{Correspondence to:}

Prof. Helotonio Carvalho

Department of Biophysics and Radiobiology

Biological Sciences Centre

Federal University of Pernambuco

Av. Prof. Moraes Rego

s/n, Cidade Universitária, 50670-901

Recife - PE

Brasil

helcarvalho@yahoo.com 